3. Лепнева С.Г. Личинки и куколки подотряда кольчатощупиковых (Annulipalpia). Фауна СССР. Т. 2. Вып. 1. М.-Л.: Наука, 1964. 563 с.

4. Росс Г., Росс Ч., Росс Д. Энтомология. Пер. с англ. М.: Мир, 1985. 576 с.

5. Иванов В.Д., Григоренко В.Н., Арефина А.Т. Отряд ручейники (Trichoptera) // Определитель пресноводных беспозвоночных России и сопредельных территорий. Т. 5. Высшие насекомые / под общ. ред. С.Я. Цалолихина. СПб.: Наука, 2001. С. 7-72.

6. Лавров И.А. Эколого-фаунистические особенности ручейников (Hexapoda: Trichoptera) бассейна реки Клязьмы: автореф. дис. ... канд. биол. наук. Владимир, 2011. 25 с.

7. Руководство по гидробиологическому мониторингу пресноводных экосистем / под ред. В.А. Абакумова. СПб.: Гидрометеоиздат, 1992. С. 131-150.

8. Степановских А.С. Экология: учебник для вузов. М.: Юнити-Дана, 2001. С. 288.

9. Определитель пресноводных беспозвоночных России и сопредельных территорий. Т. 5. Высшие насекомые / под общ. ред. С.Я. Цалолихина. СПб.: Наука, 2001. 824 с.
10. Государственный доклад «О состоянии природных ресурсов и окружающей среды республики Башкортостан в 2005 году». Уфа, 2006. 197 с.

11. Государственный доклад «О состоянии природных ресурсов и окружающей среды республики Башкортостан в 2006 году». Уфа, 2007. 200 с.

12. Государственный доклад «О состоянии природных ресурсов и окружающей среды республики Башкортостан в 2007 году». Уфа, 2008. 217 с.

13. Государственный доклад «О состоянии природных ресурсов и окружающей среды республики Башкортостан в 2008 году». Уфа, 2009. 200 с.

14. Государственный доклад «О состоянии природных ресурсов и окружающей среды республики Башкортостан в 2009 году». Уфа, 2010. 189 с.

15. Государственный доклад «О состоянии природных ресурсов и окружающей среды республики Башкортостан в 2010 году». Уфа, 2011. 343. 197 с.

16. Государственные доклады «О состоянии природных ресурсов и окружающей среды республики Башкортостан», 2011-2016 [Электронный ресурс] // http:// ecology.bashkortostan.ru/presscenter/lectures.

\title{
REPRESENTATIVES OF CADDIS FLIES OF INTEGRIPALPIA SUBORDER IN THE SYSTEM OF ENVIRONMENTAL MONITORING OF THE SOUTH URAL RIVERS
}

\section{(C) 2017}

Chaus Boris Yuryevich, candidate of biological sciences, associate professor of Biology Department Sterlitamak branch of Bashkir State University (Sterlitamak, Republic of Bashkortostan, Russian Federation)

Abstract. In the following paper the author tries to find a possibility to use larvae of caddis flies of Integripalpia suborder to increase a significance of bioindicator researches during environmental monitoring of the South Ural rivers. Analysis of caddis flies types constancy was carried out in 17 state water posts on the rivers flowing across the territory of South Ural from 2005 to 2016. As chemical characteristics such indexes as content in river waters of compounds of manganese, nickel and iron, oil products, phenols, ammonium nitrogen, coppers, zinc, COD, BOD 5 , sulfates, chlorides, nitrite nitrogen were used. Specific combinatorial index of water impurity was used as a complex index. In total constancy evolution of 7 species of larvae of caddis flies of Integripalpia suborder was analyzed. It's the first time the author has made a list of constant, additive and casual types of Integripalpia on the studied territory. The author has revealed significant correlative dependences between constancy of larvae of species of caddis flies with a number of hydro chemical indexes. The author has made regression models used to forecast constancy of larvae of Integripalpia suborder types depending on concentration of the pollutant containing in river waters.

Keywords: bioindication; caddis flies; larvae of caddis flies; Integripalpia suborder; South Ural; constancy of types; constancy evolution; hydro chemical indexes; pollutant; specific combinatorial index of water impurity; correlative models; regression models.

УДК 504.53:57.044

Статья поступила в редакцию 21.05.2017

\section{МЕТОДОЛОГИЧЕСКИЕ ПОДХОДЫ К ОЦЕНКЕ ЗАГРЯЗНЕНИЯ ТЯЖЁЛЫМИ МЕТАЛЛАМИ ПОЧВ УРБОЭКОСИСТЕМ}

(C) 2017

Юдина Елена Валериевна, начальник отдела регионального государственного экологического надзора и анализа состояния окружающей среды

Министерство природных ресурсов и экологии Республики Хакасия (2. Абакан, Российская Федерация)

Аннотация. В статье представлены данные оценки загрязнения тяжёлыми металлами почв города Абакана, основным источником поступления которых является автотранспорт. Оценка загрязнения верхних горизонтов почв, расположенных вблизи четырех основных автомагистралей города, проведена путем соотнесения с установленными нормативами, с данными содержания в почвах, испытывающих минимальную антропогенную нагрузку, данными по содержанию в почвообразующей породе территории города. Максимальные концентрации элементов зафиксированы на участке с очень высокой степенью транспортной нагрузки, что подтверждает значимость роли автотранспорта как основного источника поступления поллютантов. При расчете суммарного показателя загрязнения $\left(\mathrm{Z}_{\mathrm{c}}\right)$ для подвижных форм с использованием данных для почв с минимальной антропогенной нагрузкой, на всех автомагистралях, категория определена как «опасная». Аналогичный показатель, рассчитанный на основе данных содержания в почвообразующей породе, позволил 
определить степень загрязнения как «умеренно опасная». Анализ содержания тяжёлых металлов в почвенных профилях позволил установить в верхних почвенных горизонтах существенное превышение валовых и подвижных форм всех элементов на площадках с очень высокой и высокой степенью транспортной нагрузки, что свидетельствует об интенсивном аэрогенном поступлении поллютантов. Определена доля элементов техногенного генеза и установлен факт неравномерного распределения тяжёлых металлов в почвенном профиле и концентрации их на различных геохимических барьерах. При определении причинно-следственных связей между содержанием тяжёлых металлов и отдельными почвенными характеристиками установлена прямая зависимость от показателей: $\mathrm{pH}$, гумус, емкость катионного обмена, углекислота карбонатов, гранулометрический состав, причем в ряде случаев можно говорить о совокупном влиянии почвенных свойств на концентрацию элементов. Оценка загрязнения тяжёлыми металлами почв урбоэкосистем с использованием данных о содержании элементов в почвообразующей породе с применением профильного подхода представляется наиболее объективной.

Ключевые слова: урбоэкосистема; городская почва; антропогенное загрязнение; автотранспорт; поллютанты; тяжёлые металлы; предельно допустимая концентрация; ориентировочно допустимая концентрация; фоновые концентрации; суммарный показатель загрязнения; профильный подход; коэффициент радиальной дифференциации.

На фоне урбанизации, сопровождающейся развитием промышленных мощностей, ростом площадей жилой застройки, увеличением транспортного потока, оценка экологического состояния почвы как базового компонента урбоэкосистем становится актуальной задачей современных исследований $[1$, с. $5-8$; $2 ; 3]$.

Негативные изменения обусловлены аэрогенным поступлением большого количества поллютантов, в том числе тяжёлых металлов, которые, являясь индикаторами техногенного загрязнения, служат предметом изучения большого числа научных изысканий последних лет, посвященных эколого-геохимической оценке почв урболандшафтов, при этом основным источником их поступления признан автотранспорт $[4$, с. $68-73 ; 5$, с. $13 ; 6$, с. $11 ; 7 ; 8$, c. $44-64 ; 9 ; 10$, c. $72-83 ; 11]$.

Специфика почв как объекта с большим разнообразием внутренних и внешних связей, имеющих многоуровневую структуру и расположенных в разных функциональных зонах города, должна предполагать оценку зависимости между допустимым уровнем экологического состояния почвы и допустимым уровнем антропогенного воздействия на нее.

В силу неразработанности национальной системы экологического нормирования, на сегодняшний день для оценки степени загрязнения городских почв тяжёлыми металлами в основном используются стандартные критерии (предельно допустимые концентрации - ПДК; ориентировочно допустимые концентрации - ОДК; суммарный показатель загрязнения $\mathrm{Z}_{\mathrm{c}}$ ), в качестве альтернативных используются данные фоновых участков, подвергавшихся минимальному антропогенному воздействию, коэффициенты техногенности элементов и др. $[1$, с. $37-47 ; 12$, с. $11-13$; 13 , с. $14-15 ; 14 ; 15]$.

Целью наших исследований стало изучение содержания тяжёлых металлов в почвах промышленного и административного центра Республики Хакасия города Абакана с использованием стандартных и альтернативных методологических подходов, позволяющих получить максимально объективную оценку загрязнения.

Объектами исследования явились почвы, расположенные вблизи четырех основных автомагистралей города, которым по результатам оценки интенсивности транспортной нагрузки были условно присвоены четыре степени: I - очень высокая (улица Пушкина); II - высокая (Проспект Ленина); III - средняя (улица Ивана Ярыгина); IV - низкая (улица Ленинского Комсомола).

На каждой автомагистрали было заложено четыре площадки с учетом однородности рельефа местности, растительного покрова, жилой застройки. Пробы почв на содержание тяжёлых металлов отбирались на расстоянии 0-5 м от дорожного полотна, путем составления из 25 точечных, отобранных с глубины 0-10 см (МУ 2.1.7.730-99).

Кроме того, в целях выявления закономерностей накопления и распределения тяжёлых металлов в почвенном профиле, также было заложено четыре экспериментальных участка. Выбор участков был обусловлен наличием обнаженных в результате инженерно-строительных работ почвенных профилей глубиной до 1,5-2,0 м, а также близостью расположения к основным городским автомагистралям. По результатам оценки интенсивности транспортной нагрузки объектам исследования условно присвоены четыре степени нагрузки (I - очень высокая (профиль № 1), II - высокая (профиль № 4), III - средняя (профиль № 2), IV - низкая (профиль № 3)).

В качестве фоновых были исследованы почвы окрестностей города Абакана, отнесенные к категории земель сельскохозяйственного назначения. В настоящее время земли не используются, явные источники антропогенного воздействия отсутствуют.

Процессы, протекающие в городских почвах, определяются не только источниками и степенью антропогенного воздействия, но и свойствами, присущими самой почве, в связи с чем в почвенных образцах были определены следующие показатели: содержание органического вещества по методу Тюрина в модификации ЦИНАО (ГОСТ 26213-91), рН водной вытяжки (ГОСТ 26423-85), емкость катионного обмена (ГОСТ 17.4.4.01-84), гранулометрический состав (ГОСТ 12536-2014), углекислота карбонатов, эмиссия $\mathrm{CO}_{2}$ абсорбционным методом [16; 17, с. 401-407].

Содержание тяжёлых металлов $(\mathrm{Zn}, \mathrm{Cu}, \mathrm{Pb}, \mathrm{Cd})$ в почве определялось методом атомно-абсорбционной спектрометрии на спектрометре «КВАНТ-АФА» на базе ФГБУ Государственная станция агрохимической службы «Хакасская».

Традиционно оценка загрязнения почв урбоэкосистем тяжёлыми металлами проводится путем соотнесения полученных данных с установленными гигиеническими нормативами критических концентраций: ПДК (ГН 2.1.7.2041-06); ОДК (ГН 2.1.7.2511-09) (табл. 1). 
Юдина Е.В

Методологические подходы к оценке загрязнения тяжёлыми металлами почв..

03.02.00 - общая биология

Таблица 1 - Оценка загрязнения тяжёлыми металлами почв придорожного полотна относительно установленных нормативов ПДК, ОДК

\begin{tabular}{|c|c|c|c|c|c|c|c|}
\hline \multirow{3}{*}{$\begin{array}{c}\text { № } \\
\text { пробной } \\
\text { площадки }\end{array}$} & \multicolumn{7}{|c|}{ Кратность превышения ПДК/ОДК } \\
\hline & \multicolumn{2}{|c|}{$\mathrm{Zn}$} & \multicolumn{2}{|c|}{$\mathrm{Cu}$} & \multicolumn{2}{|c|}{$\mathrm{Pb}$} & \multirow{2}{*}{$\begin{array}{c}\mathrm{Cd} \\
\text { Валовое } \\
\text { содержание }\end{array}$} \\
\hline & $\begin{array}{c}\text { Валовое } \\
\text { содержание }\end{array}$ & $\begin{array}{c}\text { Подвижная } \\
\text { форма }\end{array}$ & $\begin{array}{c}\text { Валовое } \\
\text { содержание }\end{array}$ & $\begin{array}{c}\text { Подвижная } \\
\text { форма }\end{array}$ & $\begin{array}{c}\text { Валовое } \\
\text { содержание }\end{array}$ & $\begin{array}{c}\text { Подвижная } \\
\text { форма }\end{array}$ & \\
\hline \multicolumn{8}{|c|}{ 1. Проспект Ленина (II степень транспортной нагрузки) } \\
\hline 1.1 & 0,3 & 0,3 & 0,1 & 0,1 & $0,4 / 0,1$ & 0,2 & 0,2 \\
\hline 1.2 & 0,5 & 0,1 & 0,2 & 0,1 & $0,4 / 0,1$ & 0,1 & 0,2 \\
\hline 1.3 & 0,7 & 0,6 & 0,2 & 0,2 & $1,4 / 0,4$ & 1,3 & 0,3 \\
\hline 1.4 & 0,5 & 0,1 & 0,2 & 0,1 & $0,8 / 0,2$ & 0,7 & 0,2 \\
\hline \multicolumn{8}{|c|}{ 2. Улица Ивана Ярыгина (III степень транспортной нагрузки) } \\
\hline 2.1 & 0,9 & 0,4 & 0,2 & 0,2 & $0,7 / 0,2$ & 0,3 & 0,2 \\
\hline 2.2 & 0,8 & 0,1 & 0,1 & 0,1 & $0,1 / 0,1$ & 0,2 & 0,1 \\
\hline 2.3 & 0,9 & 0,8 & 0,2 & 0,2 & $0,6 / 0,1$ & 0,9 & 0,2 \\
\hline 2.4 & 0,4 & 0,6 & 0,1 & 0,2 & $0,5 / 0,1$ & 0,9 & 0,2 \\
\hline \multicolumn{8}{|c|}{ 3. Улица Пушкина (I степень транспортной нагрузки) } \\
\hline 3.1 & 0,5 & 1,0 & 0,4 & 0,4 & $0,7 / 0,2$ & 1,0 & 0,2 \\
\hline 3.2 & 0,5 & 0,7 & 0,2 & 0,4 & $2,0 / 0,5$ & 1,8 & 0,2 \\
\hline 3.3 & 0,7 & 1,3 & 0,5 & 2,4 & $0,7 / 0,2$ & 1,2 & 0,2 \\
\hline 3.4 & 0,4 & 1,1 & 0,3 & 1,3 & $0,6 / 0,2$ & 1,2 & 0,2 \\
\hline \multicolumn{8}{|c|}{ 4. Улица Ленинского Комсомола (IV степень транспортной нагрузки) } \\
\hline 4.1 & 0,7 & 1,5 & 0,1 & 0,2 & $0,6 / 0,1$ & 0,8 & 0,2 \\
\hline 4.2 & 0,4 & 0,9 & 0,1 & 0,3 & $0,4 / 0,1$ & 1,0 & 0,1 \\
\hline 4.3 & 0,4 & 0,9 & 0,1 & 0,2 & $0,3 / 0,1$ & 0,9 & 0,3 \\
\hline 4.4 & 0,5 & 0,7 & 0,1 & 0,2 & $0,8 / 0,2$ & 1,1 & 0,3 \\
\hline ПДК, мг/кг & - & 23,0 & - & 3,0 & 32,0 & 6,0 & - \\
\hline ОДК, мг/кг & 220,0 & - & 132,0 & - & 130,0 & - & 2,0 \\
\hline
\end{tabular}

Анализируя полученные данные, можно наблюдать на участках № 3, № 4 незначительное превышение ПДК подвижных форм Zn в 1,1-1,5 раза. Содержание валовых форм Сu не превышает установленные нормативы, кратность превышения концентрации подвижных форм $\mathrm{Cu}$ относительно ПДК на участке № 3 составила 1,3-2,4. Данные, касающиеся валового содержания $\mathrm{Pb}$, показывают превышение ПДК на участках № 1, 3 в 1,4-2,0 раза, для подвижных форм элемента на участках № 1, 3, 4 превышение ПДК для $\mathrm{Pb}$ составило 1,3; 1,8; 1,1 соответственно. Валовое содержание Сd не превышает ОДК, нормативы ПДК для данного элемента не установлены.

При сравнительном анализе содержания тяжёлых металлов относительно фоновых значений были использованы данные ФГБУ Государственная станция агрохимической службы «Хакасская» о содержании подвижных форм в почвах с/х угодий, а также собственные данные о валовом содержании в почвах окрестностей города Абакана, где антропогенное воздействие минимально.

При оценке полиэлементного загрязнение произведен расчет суммарного показателя загрязнения $\left(\mathrm{Z}_{\mathrm{c}}\right)$, равного сумме коэффициентов концентраций химических элементов $\left(K_{c}\right)$, полученных на основе соотнесения фактических и фоновых концентраций загрязнителей, и определена категория загрязнения почв по предложенной ориентировочной шкале (МУ 2.1.7.730-99) (табл. 2).

Сравнительный анализ концентраций тяжёлых металлов относительно фоновых значений установил факт превышения концентраций $\mathrm{Zn}$ на всех участках, в том числе: валового содержания в 1,2-4,0 раза, по- движных форм в 3,5-91,7 раза, с максимальными значениями на участках № 2, № 4. Значение валовых и подвижных форм $\mathrm{Cu}$ превысило фон в 1,1-3,2 и 1,9-35,5 раза соответственно. При этом максимальные значения зафиксированы на участке с I степенью транспортной нагрузки.

Факт превышения фона по содержанию $\mathrm{Pb}$ можно наблюдать на всех исследуемых участках в 1,3-7,6 раза для валового содержания и 1,9-10,7 раза для подвижных форм элемента. Высокие значения концентраций $\mathrm{Cd}$, относительно фоновых установлены на всех площадках и составили для валового содержания в 1,1-1,6, для подвижных форм 2,1-8,1.

При расчете суммарного показателя загрязнения $\left(\mathrm{Z}_{\mathrm{c}}\right)$ для валового содержания категория загрязнения почв определена как «допустимая». Вместе с тем, на основе оценки данного показателя для подвижных форм на всех участках категория загрязнения почв определена как «опасная», с максимальными значениями показателя на участках № 3 и № 4.

Анализ содержания тяжёлых металлов в почвообразующей породе (горизонт С) почвенных профилей аналогичных участков территории города позволяет констатировать тот факт, что средние значения элементов в горизонте С сопоставимы с фоновыми концентрациями поверхностных горизонтов. В связи с этим в качестве альтернативного источника, который условно можно принять за фон, использованы данные содержания тяжёлых металлов в горизонте С.

Суммарный показатель загрязнения $\left(\mathrm{Z}_{\mathrm{c}}\right)$ рассчитан на основе соотнесения фактических концентраций загрязнителей и содержанием в горизонте С (табл. 3). 
Юдина Е.В.

Таблица 2 - Оценка загрязнения тяжёлыми металлами почв придорожного полотна относительно фонового содержания

\begin{tabular}{|c|c|c|c|c|c|c|c|c|c|}
\hline \multirow{3}{*}{$\begin{array}{c}\text { № } \\
\text { пробной } \\
\text { площадки }\end{array}$} & \multicolumn{8}{|c|}{ Кратность превышения фонового содержания } & \multirow{3}{*}{$\begin{array}{c}\mathrm{Z}_{\mathrm{c}}, \text { ва- } \\
\text { ловое } \\
\text { по- } \\
\text { движ- } \\
\text { ное }\end{array}$} \\
\hline & \multicolumn{2}{|c|}{$\mathrm{Zn}$} & \multicolumn{2}{|c|}{$\mathrm{Cu}$} & \multicolumn{2}{|c|}{$\mathrm{Pb}$} & \multicolumn{2}{|c|}{$\mathrm{Cd}$} & \\
\hline & $\begin{array}{c}\text { Валовое } \\
\text { содержа- } \\
\text { ние } \\
\end{array}$ & $\begin{array}{c}\text { Подвиж- } \\
\text { ная } \\
\text { форма } \\
\end{array}$ & $\begin{array}{c}\text { Валовое } \\
\text { содержа- } \\
\text { ние } \\
\end{array}$ & $\begin{array}{c}\text { Подвиж- } \\
\text { ная } \\
\text { форма } \\
\end{array}$ & $\begin{array}{c}\text { Валовое } \\
\text { содержа- } \\
\text { ние } \\
\end{array}$ & $\begin{array}{c}\text { Подвиж- } \\
\text { ная } \\
\text { форма } \\
\end{array}$ & $\begin{array}{c}\text { Валовое } \\
\text { содержа- } \\
\text { ние } \\
\end{array}$ & $\begin{array}{c}\text { Подвиж- } \\
\text { ная } \\
\text { форма } \\
\end{array}$ & \\
\hline \multicolumn{10}{|c|}{ 1. Проспект Ленина (II степень транспортной нагрузки) } \\
\hline 1.1 & 1,2 & 18,6 & 0,9 & 0,9 & 1,4 & 1,0 & 0,9 & 2,4 & $1 / 20$ \\
\hline 1.2 & 2,3 & 3,5 & 0,9 & 0,9 & 1,7 & 0,6 & 0,8 & 2,1 & $3 / 4$ \\
\hline 1.3 & 3,0 & 38,9 & 1,1 & 2,4 & 5,4 & 7,1 & 1,6 & 6,5 & $4 / 52$ \\
\hline 1.4 & 2,3 & 7,3 & 0,9 & 1,9 & 2,9 & 4,0 & 0,9 & 2,9 & $4 / 13$ \\
\hline \multicolumn{10}{|c|}{ 2. Улица Ивана Ярыгина (III степень транспортной нагрузки) } \\
\hline 2.1 & 4,0 & 26,7 & 1,1 & 2,3 & 2,5 & 1,9 & 0,8 & 3,3 & $5 / 31$ \\
\hline 2.2 & 3,5 & 8,2 & 0,7 & 1,9 & 0,5 & 0,9 & 0,4 & 2,9 & $2 / 14$ \\
\hline 2.3 & 3,7 & 49,9 & 1,1 & 2,3 & 2,2 & 5,8 & 1,1 & 5,1 & $5 / 60$ \\
\hline 2.4 & 1,7 & 38,5 & 0,8 & 2,4 & 1,9 & 5,4 & 1,0 & 5,1 & $2 / 48$ \\
\hline \multicolumn{9}{|c|}{ 3. Улица Пушкина (I степень транспортной нагрузки) } & \\
\hline 3.1 & 2,4 & 63,1 & 2,2 & 5,6 & 2,8 & 6,0 & 1,2 & 8,1 & $6 / 80$ \\
\hline 3.2 & 2,1 & 46,2 & 1,1 & 5,8 & 7,6 & 10,7 & 0,9 & 4,0 & $12 / 61$ \\
\hline 3.3 & 2,8 & 82,3 & 3,2 & 35,5 & 2,7 & 7,3 & 0,8 & 5,0 & $9 / 127$ \\
\hline 3.4 & 1,8 & 70,3 & 1,5 & 18,7 & 2,4 & 7,3 & 1,2 & 7,1 & $4 / 100$ \\
\hline \multicolumn{10}{|c|}{ 4. Улица Ленинского Комсомола (IV степень транспортной нагрузки) } \\
\hline 4.1 & 2,9 & 91,7 & 0,8 & 2,9 & 2,2 & 4,6 & 0,9 & 4,8 & $4 / 100$ \\
\hline 4.2 & 1,6 & 53,7 & 0,9 & 3,7 & 1,5 & 5,9 & 0,7 & 2,2 & $1 / 63$ \\
\hline 4.3 & 1,5 & 60,2 & 0,7 & 3,3 & 1,3 & 5,8 & 1,5 & 3,9 & $1 / 70$ \\
\hline 4.4 & 2,2 & 45,8 & 0,9 & 2,6 & 2,9 & 6,7 & 1,4 & 5,5 & $3 / 58$ \\
\hline Фон, мг/кГ & 51,1 & 0,369 & 21,6 & 0,205 & 8,5 & 1,0 & 0,4 & 0,058 & \\
\hline
\end{tabular}

Таблица 3 - Оценка загрязнения тяжёлыми металлами почв придорожного полотна относительно содержания почвообразующей породе (горизонт С)

\begin{tabular}{|c|c|c|c|c|c|c|c|c|c|}
\hline \multirow{3}{*}{$\begin{array}{c}\text { № } \\
\text { пробной } \\
\text { площадки }\end{array}$} & \multicolumn{8}{|c|}{ Кратность превышения относительно горизонта C } & \multirow{3}{*}{$\begin{array}{c}Z_{c}, \text { ва- } \\
\text { ловое/ } \\
\text { по- } \\
\text { движ- } \\
\text { ное }\end{array}$} \\
\hline & \multicolumn{2}{|c|}{$\mathrm{Zn}$} & \multicolumn{2}{|c|}{$\mathrm{Cu}$} & \multicolumn{2}{|c|}{$\mathrm{Pb}$} & \multicolumn{2}{|c|}{$\mathrm{Cd}$} & \\
\hline & $\begin{array}{c}\text { Валовое } \\
\text { содержа- } \\
\text { ние } \\
\end{array}$ & $\begin{array}{c}\text { Подвиж- } \\
\text { ная } \\
\text { форма } \\
\end{array}$ & $\begin{array}{c}\text { Валовое } \\
\text { содержа- } \\
\text { ние } \\
\end{array}$ & $\begin{array}{c}\text { Подвиж- } \\
\text { ная } \\
\text { форма } \\
\end{array}$ & $\begin{array}{c}\text { Валовое } \\
\text { содержа- } \\
\text { ние } \\
\end{array}$ & $\begin{array}{c}\text { Подвиж- } \\
\text { ная } \\
\text { форма } \\
\end{array}$ & $\begin{array}{c}\text { Валовое } \\
\text { содержа- } \\
\text { ние } \\
\end{array}$ & $\begin{array}{c}\text { Подвиж- } \\
\text { ная } \\
\text { форма } \\
\end{array}$ & \\
\hline \multicolumn{10}{|c|}{ 1. Проспект Ленина (II степень транспортной нагрузки) } \\
\hline 1.1 & 1,4 & 1,6 & 1,1 & 0,3 & 1,2 & 0,6 & 4,7 & 3,5 & $5 / 3$ \\
\hline 1.2 & 2,6 & 0,3 & 1,2 & 0,2 & 1,4 & 0,4 & 4,3 & 3,1 & $7 / 1$ \\
\hline 1.3 & 3,4 & 3,4 & 1,4 & 0,6 & 4,4 & 4,8 & 9,0 & 9,4 & $15 / 15$ \\
\hline 1.4 & 2,6 & 0,6 & 1,2 & 0,5 & 2,3 & 2,6 & 5,4 & 4,2 & $9 / 5$ \\
\hline \multicolumn{10}{|c|}{ 2. Улица Ивана Ярыгина (III степень транспортной нагрузки) } \\
\hline 2.1 & 4,5 & 2,4 & 1,5 & 0,6 & 2,1 & 1,2 & 4,7 & 4,8 & $16 / 6$ \\
\hline 2.2 & 4,0 & 0,7 & 0,9 & 0,5 & 0,4 & 0,6 & 2,2 & 4,3 & $4,5 / 3$ \\
\hline 2.3 & 4,2 & 4,4 & 1,4 & 0,6 & 1,8 & 3,6 & 6,5 & 7,3 & $11 / 13$ \\
\hline 2.4 & 2,0 & 3,4 & 1,0 & 0,6 & 1,5 & 3,4 & 5,8 & 14,9 & $7 / 19$ \\
\hline \multicolumn{10}{|c|}{ 3. Улица Пушкина (І степень транспортной нагрузки) } \\
\hline 3.1 & 2,7 & 5,6 & 2,9 & 1,5 & 2,3 & 3,8 & 6,6 & 11,8 & $12 / 20$ \\
\hline 3.2 & 2,4 & 4,1 & 1,5 & 1,5 & 6,2 & 6,7 & 5,0 & 5,6 & $12 / 15$ \\
\hline 3.3 & 3,2 & 7,2 & 4,0 & 9,0 & 2,2 & 4,5 & 4,6 & 7,2 & $11 / 25$ \\
\hline 3.4 & 2,1 & 6,2 & 2,0 & 4,8 & 1,7 & 4,6 & 6,7 & 10,3 & $10 / 23$ \\
\hline \multicolumn{10}{|c|}{ 4. Улица Ленинского Комсомола (IV степень транспортной нагрузки) } \\
\hline 4.1 & 3,3 & 8,1 & 0,1 & 0,7 & 1,8 & 2,9 & 5,3 & 7,0 & $8 / 16$ \\
\hline 4.2 & 1,8 & 4,8 & 1,1 & 0,9 & 1,2 & 3,7 & 3,9 & 3,3 & $5 / 10$ \\
\hline 4.3 & 1,7 & 5,3 & 0,9 & 0,8 & 1,0 & 3,6 & 8,8 & 5,8 & $9 / 13$ \\
\hline 4.4 & 2,4 & 4,0 & 1,1 & 0,7 & 2,4 & 4,2 & 8,0 & 4,0 & $14 / 10$ \\
\hline $\begin{array}{c}\text { Горизонт C, } \\
\text { мГ/кг }\end{array}$ & 45,2 & 4,2 & 16,6 & 0,8 & 10,4 & 1,6 & 0,07 & 0,04 & \\
\hline
\end{tabular}


Юдина Е.В.

Методологические подходы к оценке загрязнения тяжёлыми металлами почв..

03.02.00 - общая биология

Проведя анализ полученных данных, можем наблюдать превышение валового Zn в 1,4-4,5 раза относительно горизонта $\mathrm{C}$, характерное для всех экспериментальных площадок. Аналогичную ситуацию констатируем и для подвижных форм $\mathrm{Zn}$, когда кратность превышения на большинстве площадок составила 1,6-8,1. Содержание валовых форм $\mathrm{Cu}$ превысило концентрацию элемента в горизонте С в $1,1-4,0$ раза. На участке № 3 с очень высокой степенью транспортной нагрузки установлено превышение содержания $\mathrm{Cu}$ относительно горизонта $\mathrm{C}$ в 1,59,0 раза. Кратность превышения концентрации $\mathrm{Pb}$ относительно горизонта С составила 1,2-6,2 и 1,26,7 для валовых и подвижных форм соответственно, при этом максимальные показатели установлены на участке № 3. Превышение концентрации Cd относительно горизонта С для валовых и подвижных форм составило 2,2-9,0 и 3,1-14,9 раза.

По данным расчета суммарного показателя загрязнения $\left(Z_{c}\right)$ по валовому содержанию элементов категория для почв на участках № 1, 3, 4 определена как «допустимая», на участке № 2 как «умеренно опасная». При оценке данного показателя для подвижных форм на участках № 1 установлена «допустимая» категория загрязнения, на участках № 2, 3, 4 определена «умеренно опасная» степень загрязнения.
В результате проведенной оценки загрязнения тяжёлыми металлами почв урбоэкосистем города Абакана с использованием стандартных критериев (ПДК, ОДК, фона) и альтернативных данных по их содержанию в почвообразующей породе максимальные концентрации элементов зафиксированы на участке № 3 с очень высокой степенью транспортной нагрузки, что подтверждает значимость роли автотранспорта как основного источника поступления поллютантов.

Вместе с тем концентрации отдельных элементов на участке с низкой (IV) степенью транспортной нагрузки сопоставимы с аналогичными данными на участке, где транспортная нагрузка максимальна (I), что позволяет предполагать наличие особых почвенных условий, определяющих механизмы аккумуляции элементов.

С целью установления причинно-следственных связей между содержанием металлов и почвенными характеристиками проанализированы средние показатели отдельных химических, физико-химических свойств и гранулометрического состава почв на участках с разной степенью транспортной нагрузки (табл. 4).

таблица 4 - Средние показатели отдельных физико-химических свойств почв на участках с разной степенью транспортной нагрузки

\begin{tabular}{|c|c|c|c|c|c|c|}
\hline \multirow{2}{*}{$\begin{array}{c}\text { Степень } \\
\text { нагрузки }\end{array}$} & \multicolumn{6}{|c|}{ Показатели } \\
\hline & $\begin{array}{c}\text { pH водной } \\
\text { вытяжки }\end{array}$ & $\begin{array}{c}\text { Гумус, } \\
\%\end{array}$ & $\begin{array}{l}\text { Емкость катионного } \\
\text { обмена, мг-экв } / 100 \text { г }\end{array}$ & $\begin{array}{c}\text { Углекислота } \\
\text { карбонатов, \% }\end{array}$ & $\begin{array}{c}\text { Грансостав, \% ча- } \\
\text { стицы }<0,01 \text { мм }\end{array}$ & $\begin{array}{c}\text { Эмиссия } \\
\mathrm{CO}_{2}, \text { мг/10 г }\end{array}$ \\
\hline I & 8,0 & 5,9 & 10,3 & 1,4 & 14,4 & 3,8 \\
\hline II & 8,3 & 6,3 & 22,5 & 0,6 & 22,8 & 5,3 \\
\hline III & 8,3 & 6,2 & 21,0 & 5,5 & 22,1 & 4,6 \\
\hline IV & 8,3 & 5,2 & 10,8 & 2,3 & 15,1 & 5,8 \\
\hline
\end{tabular}

На участках со II и III степенью транспортной нагрузки показатели гумуса, емкости катионного обмена, гранулометрического состава достигают максимальных значений, что объясняет низкие показатели концентраций подвижных форм $\mathrm{Zn}, \mathrm{Cu}, \mathrm{Pb}$ на данных участках. Органическое вещество значительно фиксирует тяжёлые металлы, однако содержание и состав органического вещества почв не влияет на подвижность $\mathrm{Cd}$, показатели которого практически одинаковы на всех участках. Емкость катионного обмена является обобщающим показателем, обусловленным содержанием илистой фракции и органического вещества, значения которых на участках со II и III степенью транспортной нагрузки максимальны, что, в свою очередь, определяет удерживающую способность почв по отношению к тяжёлым металлам и низкие концентрации подвижных форм.

Высокие показатели эмиссии $\mathrm{CO}_{2}(5,3$ и 4,6) на участках со II и III степенью транспортной нагрузки определяют снижение подвижности металлов на данных участках, возможно связанной с их переходом в живое вещество либо их иммобилизацией живыми организмами $[18$, с. 231-236; 19, с. 550-568; 20, c. 98-99].

Отдельные почвенные характеристики участка с низким уровнем нагрузки (IV) сопоставимы с аналогичными значениями, фиксируемыми на участке с максимальным транспортным прессом (I), это касается гумуса, емкости катионного обмена, углекисло- ты карбонатов, гранулометрического состава, что, в свою очередь, объясняет близость числовых значений концентраций подвижных форм элементов установленных на данных участках.

Что касается величины $\mathrm{pH}$, то при практически одинаковых значениях $(8,0-8,3)$ достоверно определить степень влияния на подвижность элементов на отдельных участках не представляется возможным, однако в ряде литературных источников отмечается, что в целом увеличение значения $\mathrm{pH}$ сопровождается снижением мобильности ионов тяжёлых металлов [19, с. $550-568 ; 20$, с. 96-97].

По сравнению с традиционным подходом к изучению загрязнения городских почв, подразумевающим анализ содержания тяжёлых металлов в верхних почвенных горизонтах, подход, предусматривающий определение содержания тяжёлых металлов в почвенном профиле с учетом факта неравномерного распределения тяжёлых металлов и концентрации их на различных геохимических барьерах, представляется более целесообразным. Обоснованной представляется оценка степени аккумуляции элементов в почвенном профиле с использованием коэффициента радиальной дифференциации (R) относительно почвообразующей породы: $\mathrm{R}=\mathrm{Cn} / \mathrm{Cc}$, где $\mathrm{Cn}-$ содержание элемента в горизонте $\mathrm{n}$ и $\mathrm{Cc}-$ содержание элемента в горизонте С, применяемый в том числе с целью обнаружения геохимических барьеров [13;21] (табл. 5). 
Таблица 5 - Характер профильного распределения тяжёлых металлов на основе коэффициента радиальной дифференциации (R)

\begin{tabular}{|c|c|c|c|c|c|c|c|c|}
\hline \multirow{3}{*}{$\begin{array}{c}\text { № горизонта, } \\
\text { глубина, см }\end{array}$} & \multicolumn{8}{|c|}{ Коэффициент радиальной дифференциации (R) } \\
\hline & \multicolumn{2}{|c|}{$\mathrm{Zn}$} & \multicolumn{2}{|c|}{$\mathrm{Cu}$} & \multicolumn{2}{|c|}{$\mathrm{Pb}$} & \multicolumn{2}{|c|}{$\mathrm{Cd}$} \\
\hline & $\begin{array}{c}\text { Валовое } \\
\text { содер- } \\
\text { жание }\end{array}$ & $\begin{array}{c}\text { Подвиж- } \\
\text { ная } \\
\text { форма } \\
\end{array}$ & $\begin{array}{c}\text { Валовое } \\
\text { содер- } \\
\text { жание }\end{array}$ & $\begin{array}{c}\text { Подвиж- } \\
\text { ная } \\
\text { форма } \\
\end{array}$ & $\begin{array}{c}\text { Валовое } \\
\text { содер- } \\
\text { жание }\end{array}$ & $\begin{array}{c}\text { Подвиж- } \\
\text { ная } \\
\text { форма } \\
\end{array}$ & $\begin{array}{c}\text { Валовое } \\
\text { содер- } \\
\text { жание }\end{array}$ & $\begin{array}{c}\text { Подвиж- } \\
\text { ная } \\
\text { форма }\end{array}$ \\
\hline \multicolumn{9}{|c|}{ Профиль 1} \\
\hline Горизонт I, 1, 0-50 & 14,5 & 1873,1 & 1,1 & 4,1 & 3,2 & 23,0 & 3,8 & 5,5 \\
\hline Горизонт II, 50-90 & 4,9 & 79,5 & 1,5 & 0,5 & 12,0 & 1,7 & 5,7 & 3,9 \\
\hline Горизонт III, 90-120 & 0,7 & 18,1 & 0,6 & 0,4 & 0,5 & 0,8 & 3,4 & 3,7 \\
\hline Горизонт IV, 120-170 & 1,1 & 2,9 & 1,1 & 0,7 & 1,0 & 0,8 & 2,0 & 0,3 \\
\hline \multicolumn{9}{|c|}{ Профиль 2} \\
\hline Горизонт I, 0-27 & 0,7 & 1,3 & 0,8 & 0,8 & 0,3 & 0,7 & 1,4 & 0,2 \\
\hline Горизонт II, 27-72 & 0,4 & 0,2 & 0,4 & 0,3 & 0,1 & 0,1 & 0,4 & 0,4 \\
\hline Горизонт III, 72-120 & 2,9 & 4,1 & 1,3 & 0,9 & 0,6 & 0,7 & 2,0 & 0,8 \\
\hline \multicolumn{9}{|c|}{ Профиль 3} \\
\hline Горизонт I, 0-25 & 1,0 & 1,3 & 0,9 & 0,5 & 0,8 & 0,8 & 1,2 & 2,2 \\
\hline Горизонт II, 25-80 & 1,0 & 0,02 & 0,6 & 0,4 & 0,2 & 0,1 & 0,9 & 1,4 \\
\hline Горизонт III, 80-120 & 1,4 & 3,0 & 0,9 & 0,6 & 4,1 & 8,2 & 2,1 & 2,8 \\
\hline Горизонт IV, 120-140 & 0,7 & 0,1 & 0,8 & 0,3 & 0,3 & 0,5 & 0,9 & 1,4 \\
\hline Горизонт V, 140-160 & 0,9 & 0,8 & 1,2 & 0,8 & 0,5 & 0,4 & 0,9 & 0,2 \\
\hline \multicolumn{9}{|c|}{ Профиль 4} \\
\hline Горизонт I, 0-12 & 3,9 & 66,9 & 3,0 & 3,6 & 13,3 & 20,3 & 4,2 & 3,4 \\
\hline Горизонт II, 12-52 & 2,7 & 57,5 & 1,4 & 3,7 & 9,6 & 17,9 & 2,6 & 2,7 \\
\hline Горизонт III, 52-87 & 1,1 & 2,8 & 0,9 & 0,8 & 1,7 & 0,6 & 1,2 & 0,7 \\
\hline Горизонт IV, 87-116 & 1,4 & 1,8 & 1,2 & 0,5 & 1,2 & 0,9 & 1,9 & 1,5 \\
\hline
\end{tabular}

На участках с очень высокой и высокой степенью транспортной нагрузки (Профиль № 1, Профиль № 4) в верхних почвенных горизонтах можно констатировать существенное превышение валовых и подвижных форм всех элементов, в особенности это касается подвижных форм Zn, для которого кратность превышения относительно горизонта С составила 1873,1 и 66,9 , что свидетельствует об интенсивном аэрогенном поступлении поллютантов и аккумуляции их в верхних почвенных горизонтах. Профили № 2, 3 характеризуются неравномерным распределением концентрации как валового содержания, так и подвижных форм элементов. Например, наблюдается снижение концентрации в горизонтах II и значительный ее рост в горизонте III на глубине 72-120 см, что объясняется песчаным гранулометрическим составом, способствующим формированию промывного водного режима и миграции элементов в нижние горизонты.

Определение показателя техногенности ( $\mathrm{Tg})$, под которым понимается доля техногенного элемента в процентах от валового содержания в почве, позволяет установить долю элемента техногенного генеза [13, с. 45-46; 14]. Так, доля техногенности в верхних почвенных горизонтах на участках с очень высокой (Профиль № 1) и высокой степенью (Профиль № 4) транспортной нагрузки для Zn составляет 93\% и 74\%, для $\mathrm{Pb}-69 \%$ и 92\%, для $\mathrm{Cd}-73 \%$ и 76\%. Показатель техногенности Сu в Профиле № 4 составил $66 \%$.

Процессы аккумуляции и миграции тяжёлых металлов в городских почвах определяются не только источниками поступления загрязняющих веществ и степенью антропогенного воздействия, но и свойствами, присущими самой почве, в связи с чем при оценке уровня загрязнения, анализе механизмов, связанных с накоплением и распределением тяжёлых металлов, немаловажным является установление причинно-следственных связей между их содержанием и отдельными почвенными характеристиками $[1 ; 21]$.

Проведенный корреляционный анализ позволяет установить взаимосвязь между показателем $\mathrm{pH}$ и содержанием тяжёлых металлов. Факт прямой корреляционной зависимости, обусловленный увеличением щелочности почв, может быть следствием привнесения карбонатных щебней при строительстве автомагистралей, применения антигололедных смесей и других факторов. В наибольшей степени это проявляется в отношении $\mathrm{Cu}$ и $\mathrm{Cd}$, в профилях № 1, 2, 4, для которых выявлена значительная корреляция валовых и подвижных форм (коэффициент корреляции 0,9). В профиле № 3 положительная корреляция установлена для валового содержания $\mathrm{Zn}$, валовых и подвижных форм $\mathrm{Pb}$ и $\mathrm{Cd}$.

Значительная корреляция с показателем $\mathrm{pH}$ обусловлена свойствами тяжёлых металлов; так, $\mathrm{Cu}$ в нейтральной и щелочной среде малоподвижна и на щелочном барьере осаждается во вторичные минералы. Так как растворимость Сd зависит от $\mathrm{pH}$, то особенно благоприятные условия для его концентрации формируются на щелочных геохимических барьерах карбонатных почв. На миграцию Zn, имеющего по- 
стоянную валентность, главное влияние оказывают изменение щелочно-кислотных условий и сорбционные процессы. То же касается и $\mathrm{Pb}$, который в нейтральной и щелочной среде образует малоподвижные комплексные соединения $\left[\mathrm{Pb}(\mathrm{OH})_{2}\right] 2, \quad\left[\mathrm{~Pb}(\mathrm{OH})_{3}\right]$ $[18$, с. $231-236 ; 19$, с. $550-568 ; 22]$.

Полученные результаты позволяют проследить связь содержания тяжёлых металлов с содержанием гумуса, что можно было предвидеть, так как высокое содержание органического вещества свидетельствует о значительной сорбционной способности почв, когда гумусовые и низкомолекулярные органические кислоты образуют с тяжёлыми металлами сложные комплексные соединения. Положительная корреляция наблюдается во всех профилях, характерна как для валовых, так и подвижных форм всех металлов (коэффициент корреляции 0,2-0,9) [19, с. 550-568; 20, с. 95-96; 22].

Тяжёлые металлы, являясь катионогенными элементами, показывают прямую корреляцию с показателем емкости катионного обмена в профилях № 1, 2,4 (коэффициент корреляции 0,2-0,9). Однако в профиле № 3 данная закономерность характерна только для $\mathrm{Cu}$ (коэффициент корреляции 0,8), которая, являясь одним из лучших комплексообразователей, в присутствии органических веществ образует прочные фульватные и гуматные органоминеральные комплексы [19, с. 550-568; 20, с. 98; 22].

Факт прямого влияния гранулометрического состава на содержание тяжёлых металлов прослеживается не для всех металлов и не на всех исследуемых профилях, однако можно наблюдать высокие показатели корреляции в профилях, где отмечен факт существенной зависимости содержания тяжёлых металлов от содержания гумуса и величины емкости катионного обмена (в профиле 1 для $\mathrm{Cd}$, в профиле № 3 для $\mathrm{Cu}$, в профиле № 2 для всех металлов), что свидетельствует о совокупном влиянии почвенных свойств на концентрацию элементов в каждом конкретном профиле [22].

Таким образом, использование методологических подходов как традиционных, так и альтернативных позволило выявить общую закономерность, обусловленную наличием высоких значений концентраций тяжёлых металлов на участках с максимальной интенсивностью транспортной нагрузки, что подтверждает роль автотранспорта как основного источника поступления рассматриваемых поллютантов.

Установленные превышения концентраций тяжёлых металлов, относительно ПДК, ОДК, фона, горизонта C, а также категории загрязнения, определенные на основе суммарного показателя загрязнения $\left(Z_{c}\right)$ в основном касаются подвижных форм элементов, что свидетельствует о загрязненности почв поллютантами [23].

Подтверждена определяющая роль почвенных свойств, присущих локальным участкам, в аккумуляции тяжёлых металлов как в верхних горизонтах почв, так и на геохимических барьерах почвенного профиля.

Вместе с тем, использование в качестве критериев оценки загрязнения ПДК, которые установлены не для всех элементов, ОДК, ориентированные на отдельные группы почв с учетом гранулометрического состава и $\mathrm{pH}$, фоновых концентраций, которые помимо удаленности от источника загрязнения характеризуются высокой степенью дифференциации, не обеспечивает должную степень достоверности проводимой оценки.

Суммарный показатель $\left(Z_{c}\right)$ также не обладает достаточной степенью объективности, так как не учитывает класс опасности элемента, при этом может возникнуть ситуация, когда при одном и том же показателе $\mathrm{Z}_{\mathrm{c}}$ и соответственно отнесении к одной категории загрязнения, степень антропогенного воздействия может быть ошибочно преувеличена (при превышении концентрации $\mathrm{Cu}$, элемента II класса опасности) либо недооценена (при превышении концентрации $\mathrm{Cd}, \mathrm{Pb}$, элементов I класса опасности) [20, c. 134].

При оценке загрязнения городских почв тяжёлыми металлами более обоснованным представляется профильный подход, основанный на анализе аккумуляции тяжёлых металлов в почвенном профиле относительно почвообразующей породы, позволяющий более достоверно установить долю элемента техногенного генеза.

Существующая система оценки загрязнения почвенного покрова, разработанная в рамках санитарногигиенического нормирования, без учета источников загрязнения, природно-климатических условий региона, естественного геохимического фона, не позволяет провести объективную оценку ущерба, нанесенного почвенному покрову как компоненту урбоэкосистемы, характеризующемуся высокой степенью дифференциации элементного состава, свойств, адаптационных возможностей, что обусловливает необходимость разработки национальной системы экологического нормирования, базирующейся на региональной основе и с учетом экологической емкости среды [1, с. 47; 12, с. 197-198].

\section{СПИСОК ЛИТЕРАТУРЫ:}

1. Дабахов М.В., Дабахова Е.В., Титова В.И. Экологическая оценка почв урбанизированных ландшафтов Н. Новгород: Изд-во ВВАГС, 2015. 305 с.

2. Строганова М.Н., Прокофьева Т.В., Прохоров А.Н., Лысак Л.В., Сизов А.П., Яковлев А.С. Экологическое состояние городских почв и стоимостная оценка земель // Почвоведение. 2003. № 7. С. 867875.

3. Терехова В.А., Пукальчик М.А., Яковлев А.С. «Триадный» подход к экологической оценке городских почв // Почвоведение. 2014. № 9. С. 1145-1152.

4. Корчагина К.В. Оценка загрязнения городских почв тяжёлыми металлами с учетом профильного распределения их объемных концентраций: дис. ... канд. биол. наук. М., 2014. 145 с.

5. Рылова Н.Г. Трансформация почвенного покрова в условиях промышленного города и ее воздействие на растительность (на примере г. Ижевска): автореф. дис. ... канд. биол. наук. Ижевск, 2003. 20 с.

6. Прусаченко А.В. Экотоксикологическая оценка загрязнений тяжёлыми металлами урбаноземов города Курска: автореф. дис. ... канд. биол. наук. М., $2011.20 \mathrm{c}$. 
7. Вишневая Ю.С., Попова А.Ф. Влияние автотранспорта на загрязнение почвенного покрова г. Архангельска тяжёлыми металлами // Вестник САФУ. Сер.: Естеств. науки. 2016. № 2. С. 32-41.

8. Забелина О.Н. Оценка экологического состояния почвы городских рекреационных территорий на основании показателей биологической активности (на примере г. Владимира): дис. ... канд. биол. наук. Владимир, 2014. $147 \mathrm{c}$.

9. Юдина Е.В. Экологическое состояние почвенного покрова города Абакана // Экология урбанизированных территорий. 2015. № 3. С. 44-49.

10. Никитенко М.А. Влияние урбанизации на трансформацию почвенного покрова и условия функционирования древесных растений городов среднего Предуралья (на примере г. Сарапула и г. Камбарки): дис. ... канд. биол. наук. Ижевск, 2007. 193 с.

11. Петрова А.В. Эколого-геохимическая оценка почв Восточного Донбасса // Геохимия ландшафтов (к 100-летию А.И. Перельмана): докл. всерос. науч. конф. Москва, 18-20 октября 2016 г. М.: Географический факультет МГУ, 2016. С. 413-417.

12. Экологическое нормирование и управление качеством почв и земель / под общ. ред. С.А. Шобы, А.С. Яковлева, Н.Г. Рыбальского. М.: НИА-Природа, 2013. $310 \mathrm{c}$.

13. Водяницкий Ю.Н. Тяжёлые и сверхтяжёлые металлы и металлоиды в загрязненных почвах. М.: ГНУ Почвенный институт им. В.В. Докучаева, Россельхозакадемия, 2009. 96 с.

14. Водяницкий Ю.Н., Савичев А.Т., Рогова О.Б. Содержание сверхтяжёлых металлов (Ba, $\mathrm{La}, \mathrm{Ce})$ в почвах Череповецкой техногеохимической аномалии
// Бюллетень Почвенного института имени В.В. Докучаева. 2010. № 65. С. 58-64.

15. Водяницкий Ю.Н., Яковлев А.С. Оценка загрязнения почвы по содержанию тяжёлых металлов в профиле // Почвоведение. 2011. № 3. С. 329-335.

16. Методические указания по определению углекислоты карбонатов в почвах / сост. С.Г. Самохвалов. М.: ЦИНАО, 1984. 22 с.

17. Методы исследований органического вещества почв. М.: Россельхозакадемия - ГНУ ВНИПТИОУ, 2005. $521 \mathrm{c}$.

18. Алексеенко В.А., Алексеенко А.В. Химические элементы в геохимических системах. Кларки почв селитебных ландшафтов. Ростов-на-Дону: Издво ЮФУ, 2013. 388 с.

19. Перельман А.И., Касимов Н.С. Геохимия ландшафта. М.: Астрея-2000, 1999. 610 с.

20. Дабахов М.В., Дабахова Е.В., Титова В.И. Экотоксикология и проблемы нормирования. Н. Новгород: Изд-во ВВАГС, 2005. 165 с.

21. Юдина Е.В. Содержание тяжёлых металлов $(\mathrm{Pb}, \mathrm{Cd}, \mathrm{Cu}, \mathrm{Zn})$ в почвах города Абакана // Геохимия ландшафтов (к 100-летию А.И. Перельмана): доклады всерос. науч. конф. Москва, 18-20 октября 2016 г. М.: Географический факультет МГУ, 2016. С. 663666.

22. Юдина Е.В. Особенности накопления и распределения тяжёлых металлов в почвах города Абакана // Вестник Красноярского государственного аграрного университета. 2016. № 9. С. 32-39.

23. Водяницкий Ю.Н. Критерии техногенности тяжёлых металлов и металлоидов в почвах (литературный обзор) // Почвоведение. 2009. № 9. С. 11331141.

\section{METHODOLOGICAL APPROACHES TO THE ASSESSMENT OF HEAVY METAL CONTAMINATION IN URBAN ECOSYSTEMS SOILS}

(C) 2017

Yudina Elena Valerievna, head of Regional State

Environmental Monitoring and Analysis Environmental Department Ministry of Natural Resources and Environment of the Republic of Khakassia (Abakan, Russian Federation)

Abstract. The paper presents the assessment of heavy metal pollution of Abakan soils, the main source of which is motor transport. The pollution assessment of the upper horizons soils located near four main highways of the city was conducted under established standards. The maximum concentration of elements was recorded in the area with very high traffic, which confirms the importance of the role of motor transport as the main source of pollutants. When calculating the total pollution index $\left(\mathrm{Z}_{\mathrm{c}}\right)$ all highways were in a «dangerous» category. A similar indicator calculated on the basis of the data content in the soil-forming rock, allowed us to determine the degree of pollution as «moderately hazardous». Analysis of heavy metals content in soil profiles has allowed to establish in the upper soil horizons, a significant excess of gross and mobile forms of all elements at sites with very high and high degree of traffic load, which indicates intense aerogenic intake of pollutants. Determined the proportion of elements of anthropogenic origin and the fact of the uneven distribution of heavy metals in the soil profile and their concentration in different geochemical barriers. When determining causal relationships between heavy metal content and separate soil characteristics we have found a direct dependence on the following parameters: $\mathrm{pH}$, humus, cation exchange capacity, carbon dioxide, carbonates, particle size distribution, and in some cases we can talk about complex influence of soil properties on the concentration of elements. Assessment of heavy metal contamination in urban ecosystems soils, using the data content of elements in soil-forming rock with the use of the profile approach is the most objective.

Keywords: urban ecosystem; urban soil; anthropogenic pollution; motor transport; pollutants; heavy metals; maximum permissible concentration; tentatively permissible concentration; background concentration; total contamination index; profile approach; radial differentiation ratio. 